\title{
THE EFFECTS OF THE PEDAGOGICAL EXPERIENCE ON THE QUALITY OF TEACHER EDUCATION
}

\author{
Dr. Tatjana Koteva-Mojsovska, "Ss Cyril and Methodius” University, Faculty of Pedagogy “St Kliment \\ Ohridski", Skopje, Republic of Macedonia \\ E-mail: tanja.koteva@yahoo.com \\ Dr. Suzana Nikodinovska Bancotovska, "Ss Cyril and Methodius” University, Faculty of Pedagogy "St Kliment \\ Ohridski”, Skopje, Republic of Macedonia \\ E-mail: suzi.niko.bancot@gmail.com
}

\begin{abstract}
Faculties should ensure integration of science and teaching: science that constantly evolves following the changes in scientific thought and teaching that incorporates these changes in their own organization. So there is a need of including the students, who are prepare for teachers, in the process of pedagogical experience during their study. Pedagogical experience is a completed with a pedagogical practice and hospitation on one side and theoretical knowledge on the other side. Pedagogical experience is a kind of activities that students are involved in the educational process.

Considering the importance of these activities, we made a research to determine the effects of pedagogical experience of students in the fourth year of studies at the Pedagogical Faculty in Skopje. This research is guided by two assumptions: 1. Pedagogical experience as an integral part of studies has positive effects on the quality of initial teacher education and educators; 2 . The organization of pedagogical internship does not fully satisfy the educational-applicative needs of students and objectives of the internship.
\end{abstract}

During the survey, we have found that the students have good theoretical knowledge about the educational process and are successful in selecting topics for discussion with the competent persons in institutions. But they are not initiative enough and they are not sufficiently active in the process that have no direct obligation to implement and to record. Because of that, students have to be well prepared and instructed for all activities through the practice that will relate to their overall engagement as teachers.It shows that there is a necessity to redefine the structure, objectives, content and organization of the internship.

Keywords: pedagogical expirience, pedagogical internship, teacher education, practical teaching, educator, teacher.

Corresponding Author

Dr. Tatjana Koteva-Mojsovska, "Ss Cyril and Methodius" University, Faculty of Pedagogy "St

Kliment Ohridski", Skopje, Republic of Macedonia E-mail: tanja.koteva@yahoo.com
Received: November, 15.2015. Revised: December, 06.2015.

Accepted: December, 09.2015. Original Research

UDK 371.26-057.875:[378.6:37(497.7)"2014/2015" 159.947.5.072-057.875(497.7)"2014/2015"

\section{INTRODUCTION}

There have been changes in higher education as a result of many changes in the modern life. It takes modern higher education institutions to meet the requirements in terms of education of teachers. Faculties should ensure integration of science and practical teaching: a science that constantly evolves following the changes in scientific thought and teaching that incorporates these changes in their own organization.Studying the faculties that educates teachers involves professional training in terms of scientific and academic achievements on the one hand and the study of pedagogical and didactic-methodological content, strategies and models of educational work, on the other hand (Koteva-Mojsovska-Tatiana 2008.)

The future teachers acquire knowledge and skills that represent the profession they have chosen. Theoretical knowledge is necessary but not always sufficient in preparing the appropriate staff. Theoretical knowledge needs to be supported by appropriate practical skills and knowledge. The practical training is able to provide adequate practical support of theoretical knowledge. "The future teachers through practical experience have the chance to be involved in the process of practical teaching. Evidence suggests that teacher learning is enhanced in school practice contexts as professional communities - where teachers get along and have a regular professional dialogue with one another, with strong leadership and adequate teaching resources" (Caena, F., 2014.). The future teachers through practical experience have the chance to be involved in the process of practical teaching.

Pedagogical experience is a completed with a pedagogical practice and demonstration classes on one side and theoretical knowledge 
on the other side. Pedagogical experience is the kind of activities that students are involved in the educational process. Students activities are organized and systematized according to previously prepared plan. Pedagogical experience includes the involvement of students in the organization and implementation of regular lessons or educational activities in the partner institution. Also, students involved in outside educational activities taking place in the partner institution in that period. In the implementation of pedagogical practice, students can gain performance of the overall organization of life and work in the kindergarten/school. In some educational system, it is called professional integration (Sacilotto-Vasylenko, M., 2010.). Students realize activities/classes which previously are instructed by the mentor. The experience is implemented in order to complete the process of practical training, with appropriate involvement in the educational activities of the kindergarten/school. During the pedagogical experience, students are included in all educational activities, such as the various sections, parent meetings, events, organizing leisure activities, lessons and so on. During the pedagogical experience, students develop different kinds of skills such as an observation, thinking, understanding, planning, reflection, discussion, evaluation, etc.

\section{MATERIALS AND METHODS}

In the academic year 2014/15. we conducted research with students of the fourth year of studies at the Faculty of Pedagogy. The object of the research was testing the efficiency of the pedagogical internship. The survey was conducted in order to determine the effects of pedagogical experience. The survey covered 40 students in the fourth year of studies at institutes of pre-school education and elementary school teaching in Macedonian and Albanian language. This research is guided by two assumptions:

1. Pedagogical experience as an integral part of studies has positive effects on the quality of initial teacher education and educators;

2. The organization of pedagogical internship does not fully satisfy the educational-applicative needs of students and objectives of the internship.
The study used surveys, interviews, and analysis of documents. The questionnaire was designed for students - trainees, and in it there were issues of open and closed. Besides the questionnaire, with students and some teachers/educators and we conducted the unstructured interview in order to get relevant information on issues that were the focus of our interest. In order to get a fuller picture of activation of the students as well as their commitment to the problems of educational practice, we realized and protocol analysis of the documents which they led during the internship. In seniority had adequate working conditions in which each student was constantly active. This means that one mentor tutor/teacher worked with three students. According to the number of mentors, it was the smallest possible number of students in a group or separately.

Our interest through research focused on several issues: the competence of students for practical application of knowledge, their interest in different aspects of the educational process, creative and innovative potential of students in accordance with the acquired knowledge, opportunities for individual activation of students in the educational process, as well as topics of conversation that students realize with educators/teachers during their practical activities, preparation of mentors for mentoring students - trainees. At the end of the questionnaire, we are interested in the opinion of students and their suggestions and proposals for improving the practical teaching in initial education of future teachers and mentors.

Pedagogical experience has positively effected to the systemizing theoretical students knowledge.

\section{RESULTS AND DISSCUSION}

Data analysis resulted in interesting findings related to the pedagogical experience of students in the fourth year of study. But in this paper are shown results in specific answers to the respondents. Accordingly that regarding the competence of students-trainees for practical application of theoretical knowledge we are interested in whether and what kind of intervention by the mentor is needed. (Никодиновска-Банчотовска, С., 2008.). 
The results are shown in the following Table 1:

Table 1. Student needs for intervention in the activities during internship

\begin{tabular}{|c|c|c|c|c|c|c|c|c|c|c|c|c|c|c|c|c|}
\hline \multicolumn{3}{|c|}{ Activities Preparation } & \multicolumn{2}{|c|}{$\begin{array}{l}\text { Impleme- } \\
\text { ntation }\end{array}$} & \multicolumn{2}{|c|}{$\begin{array}{l}\text { Records of } \\
\text { activities }\end{array}$} & \multicolumn{2}{|c|}{$\begin{array}{l}\text { Cooperation } \\
\text { with parents }\end{array}$} & \multicolumn{2}{|c|}{ Valuation } & \multicolumn{2}{|c|}{$\begin{array}{l}\text { Applica- } \\
\text { tion of } \\
\text { standards }\end{array}$} & \multicolumn{2}{|c|}{$\begin{array}{c}\text { Motivating } \\
\text { students }\end{array}$} & \multicolumn{2}{|c|}{$\begin{array}{c}\text { In } \\
\text { specific } \\
\text { situation } \\
\end{array}$} \\
\hline $\begin{array}{l}\text { Need for } \\
\text { Intervention }\end{array}$ & $\mathrm{f}$ & $\%$ & $f$ & $\%$ & $f$ & $\%$ & f & $\%$ & f & $\%$ & $f$ & $\%$ & $f$ & $\%$ & $f$ & $\%$ \\
\hline $\begin{array}{l}\text { Full } \\
\text { intervention }\end{array}$ & 6 & 15 & 12 & 30 & 26 & 65 & 35 & 87,5 & 34 & 85 & 17 & 42,5 & 17 & 42,5 & 21 & 52,5 \\
\hline $\begin{array}{l}\text { Partial } \\
\text { intervention }\end{array}$ & 11 & 27,5 & 7 & 7,5 & 11 & 27,5 & 5 & 12,5 & 6 & 15 & 14 & 35 & 3 & 7,5 & 2 & 5 \\
\hline $\begin{array}{l}\text { Without } \\
\text { intervention }\end{array}$ & 23 & 57,5 & 21 & 52,5 & 3 & 7,5 & l & 1 & 1 & 1 & 9 & 22,5 & 20 & 50 & 17 & 42,5 \\
\hline Total & 40 & 100 & 40 & 100 & 40 & 100 & 40 & 100 & 40 & 100 & 40 & 100 & 40 & 100 & 40 & 100 \\
\hline
\end{tabular}

From the table, it is evident that most of the students have need of intervention in the evaluation of the educational process $(85 \%)$ and in the cooperation with parents $(87.5 \%)$. This certainly can be justified by the fact that they showed no initiative for the implementation of these key issues. The interview with students showed that teachers/educators avoided situations in which students should realize their competencies.

In this study, we are interested in the opinion of students regarding the effects of pedagogical experience. Namely, we wanted to know whether the seniority helped systematize the knowledge acquired through theoretical part of initial teacher education. That is the answer we received in addition to the positive effects of pedagogical experience. In fact, most of the respondents, or $82.5 \%$ of the total, prefer this answer: the pedagogical experience helped me to systematize my theoretical knowledge. For the answer: The seniority partially helped me to systematize my theoretical knowledge, opted 6 respondents or $15 \%$ of the total while only one respondent stated that seniority did not help him to systematize theoretical knowledge. This suggests that pedagogical experience as an integral part of initial education has an important role in shaping the educational staff.

In terms of efficiency, also we were interested in whether students during internship shown initiative for the organization and implementation of activities they need. In this case, we wanted to know whether the students (respondents) have initiated activities that are important for their profiling, but which are not currently active within the school/kindergarten and are not placed in the current period. Or include practice only by the available activities which are offered by partner educational institution. The responses received are read in the second table.

Table 2. Initiative of students for new activities during the seniority

\begin{tabular}{lcc}
\hline \multirow{2}{*}{ Students: } & $\begin{array}{c}\text { Frequency and } \\
\text { percentage of } \\
\text { initiative }\end{array}$ \\
\cline { 2 - 3 } & $\mathrm{f}$ & $\%$ \\
\hline Initiate new activities & 3 & 7,5 \\
\hline They engage only in activities offered & 35 & 87,5 \\
\hline No response to a given initiative & 2 & 5 \\
\hline Total & 40 & 100 \\
\hline
\end{tabular}

From said table, it is evident that students do not show initiative for activities that are important for their service. Through interviews with them, we found that this is because they do not know whether they have the right to initiate and content of the program outside the school/kindergarten in a given period.

As far as the activation of students in activities necessary to realize the pedagogical internship, we were interested in whether and to what extent (fully, partially or not at all) they are activated in the process of their implementation (Table 3 ). The responses confirmed some information obtained through other questions in the questionnaire and through conducted interview.

Table 3. Activation of students during internship

\begin{tabular}{lcccccccc}
\hline \multirow{2}{*}{\multicolumn{1}{c}{ Type of activity }} & \multicolumn{2}{c}{$\begin{array}{c}\text { Fully } \\
\text { active }\end{array}$} & $\begin{array}{c}\text { Partially } \\
\text { active }\end{array}$ & inactive & \multicolumn{2}{c}{ total } \\
\cline { 2 - 11 } & $\mathrm{f}$ & $\%$ & $\mathrm{f}$ & $\%$ & $\mathrm{f}$ & $\%$ & $\mathrm{f}$ & $\%$ \\
\hline Realize school class/ activity & 40 & 100 & $/$ & $/$ & $/$ & $/$ & 40 & 100 \\
\hline Writing preparation for class & 40 & 100 & $/$ & $/$ & $/$ & $/$ & 40 & 100 \\
\hline Recording implemented activities & 40 & 100 & $/$ & $/$ & $/$ & $/$ & 40 & 100 \\
\hline Evaluation Process & $/$ & $/$ & 2 & 5 & 38 & 95 & 40 & 100 \\
\hline Cooperation with parents & $/$ & $/$ & 3 & 7,5 & 37 & 92,5 & 40 & 100 \\
\hline
\end{tabular}


In connection with the activation of students in different types of activities, it is evident that all students $(100 \%)$ are fully involved in activities that had an obligation to implement them (preparation, implementation, and records per hour). Interesting for us is the inclusion of students in the teaching process. Namely, in this type of activities students showed $100 \%$ full activation. But this response, however, refers only to the classes which was assigned to realize them, for a total of 6 hours from 15 days pedagogical experience. Because students have to take the full role of the teacher during the days of internship, this situation is not satisfactory. This is probably due to the majority of students which must rotate in a group or department versus the number of partner educational institutions that perform an internship and versus the number of mentors, mentors, and tutors. In other situations, a small number of students interns shown its activation. These situations actually relate to activities which in the current period are not provided within the school/kindergarten. It coincides with the data obtained by the issue of the initiative of the side of students.

On the questions What are your general expressions from the whole educational activity in the school. The responses have been ranked according to percentage obtained from analysis:

1. methods of the work- 22 answers or $55 \%$

2. adequately arranged interior and exterior- 11 answers or $27,5 \%$

3. ways of planning and programming the educational work -4 answers or $10 \%$

4. wholesome realization of the educational process- 3 answers or $7,5 \%$.

In terms of types of activities during the realization of the practice, we are interested in the opinion of students about the priority on the following activities: Maintenance of educational activities and classes; Chat with educator/teacher; conversation with the director; talk with counselor/psychologist, activities for monitoring and insight into pedagogical documentation. Among other activities, a huge part of students (38 students or 95\%) give an accent on the involvement in maintaining educational activities and classes. In 90\% of cases (36 students/participants), they have decided to talk to the teacher as an important activity, while 29 respondents or $72.5 \%$ of the surveyed students give priority to the conversation with the counselor/psychologist. Interestingly, the conversation with the director and the monitoring of various kinds of activities are placed on the lowest level of priority in the opinion of students respondents. In an interview conducted with these respondents said they had no opportunity to be in contact with the director, what confirms the statement that in the partner institutions do not adapt activities and events based on student needs and goals of the pedagogical experience. In addition to this is the interview with the teachers and educators in which it is determined that one part of them received some training for mentoring students, but it was focused on the interpretation of the manual that applies to all three parts of teaching practice with students (pedagogical practice, attending and pedagogical experience). The interview also showed that instruction is not adapted by teachers and educators to student's needs and the needs arising from the objectives of the pedagogical experience. The period for implementation of the activities was also short ( 3 weeks).

The question that referred to the themes that have been the subject of discussion between students and tutor/teacher was from the open source. In this respect, the results show that the most common topics of conversation were: the organization of school hours, the content of pedagogical Documentation and ways of its guidance, treatment and motivating children/students, the organization of the day in kindergarten, working conditions, monitoring developmental achievements of the children, the openness of kindergarten/ school, etc. Students who realized experience in kindergarten were interested in adopting children. Students who realized experience in primary schools showed interest in contemporary learning strategies and parental involvement in education.

The survey was completed with proposals for improving the quality of pedagogical experience obtained by the students who are preparing for teachers and educators. In fact, they said that the internship should be longer; should have fewer students together in the same educational group/grade; there is a need to keep a diary of realization of all activities for an internship in the kindergarten/school etc. Also, students propose a final report that will summarize the experiences and knowledge gained through internship and it will be a theme for discussing with their teachers in the initial education. 


\section{CONCLUSION}

From the analysis and interpretation of the survey results, one can conclude that the pedagogical experience has positively effect to the systemizing theoretical students' knowledge. The processing of the data showed that students have good theoretical knowledge about educational processes and are successful in selecting topics for discussion with the competent persons in institutions. But on the other hand, they are not enough initiative and are not sufficiently active in processes that have no direct obligation to implement and recorded. This part is interesting that there is not enough initiative and motivation and by teachers / educators in practice. Regarding the organization of pedagogical experience, we concluded that in the current period in partner educational institutions there is not adjust on the educational process according to the needs of students and the purposes of the internship. We estimate that this part of the implementation of the internship should be governed by a written cooperation agreement between the Faculty and its partner educational institutions.

It can also conclude that during the seniority students demonstrate competence in the practical implementation of knowledge. Only in some activities that we appreciate as more complex and sensitive requiring an intervention in terms of their planning, realization, and understanding. It is justified given that the internship process is implemented for the duration of the studies.

Given that students are not distributed by one of them in a group or department they are not able to realize all the activities or classes under a program for them. Accordingly, over the course of an internship does not realize a sufficient number of classes and activities in accordance with the students needs involved in the process. $\mathrm{n}$ addition to all can be concluded that the students did not take the full role of the teacher / educator during the internship, which could jeopardize the smooth process of practicing the theoretical knowledge. This means students to be well prepared and instructed for all activities through the practice that will relate to their overall engagement as teachers. Namely the realization of practical teaching students only in terms of maintenance of educational activities and lessons will not provide the complete experience of student-teacher activities, and fully experience the educational atmosphere in the institution. That would mean and unprofessional ap- proach to the development of future teachers and educators.

Hence, it can conclude that these findings resulting from analysis of the data confirmed the two hypotheses laid the basis for research or:

1. Pedagogical experience as an integral part of studies have positive effects on the quality of initial teacher education and educators;

2. The organizational structure of the pedagogical experience does not fully satisfy educational needs of students and objectives of the internship.

Considering the role of the pedagogical experience on the quality of the education of future teachers and educators, it is necessary redefining its structure, objectives, content and organization of the internship.

\section{ACKNOWLEDGMENTS}

For this research we express acknowledgment to the students of the Pedagogical Faculty in Skopje that were involved in the process, as well as to the professional staff in educational institutions that enabled us to observe the process and to do interview during the pedagogical experience of the students.

\section{Conflict of interests}

Authors declare no conflict of interests.

\section{REFERENCES}

Caena, F. (2014). Teacher Competence Frameworks in Europe: policy-as-discourse and policy-aspractice. European Journal of Education, 49(3), 311-331.

Career Entry profile for Newly Qualified Teachers (Standards for the Award of Qualified Teacher Status), 1997. London: Teacher Training Agency.

DeRoche, E. F. (1987). An administrator's guide for evaluating programs and personnel: An effective schools approach. Publication Sales.

Koteva-Mojsovska, T. (2008). Profiling Modern Teacher - Reality and Needs Contemporary Intentions in Education, University "Ss. Cyril and methodius" Skopje, Faculty of Pedagogy "Ss. Kliment Ohridski" Skopje.

McMillan, J. H., \& Wergin, J. F. (1998). Understanding and Evaluating Educational Research. PrenticeHall, Inc., One Lake Street, Upper Saddle River, NJ 07458 .

Moyles, J. R. (1988). Self-evaluation: a primary teacher's guide. Delmar Pub.

National Standards for Qualified Teacher Status (1998). London: Teacher Training Agency, G. Britain.

Sacilotto-Vasylenko, M. (2009). Improving policy and 
(IJCRSEE) International Journal of Cognitive Research in Science, Engineering and Education Vol. 3, No.2, 2015.

practice of teacher induction into the profession. ADVANCING QUALITY CULTURES FOR TEACHER EDUCATION IN EUROPE: Tensions and Opportunities, 121.

Schratz, M. (2009). What is a 'European teacher'. ENTEP the first ten years after Bologna, 97-102.

Никодиновска-Банчотовска, C, (2008). Професионалните компетенции на наставниците, Академски печат, Скопје. 